\title{
Geleentheidsrede
}

\section{Die sinvraag in ons verhouding tot die natuur en in die geskiedenis van die IRS (1962-1999) ${ }^{1}$}

\author{
B.J. van der Walt
}

\author{
"Alles tevergeefs, sê die Prediker, \\ alles tevergeefs, \\ dit is alles tevergeefs!"
}

(Pred. 1:2)

\section{Inleiding: die grootste lewensvraag}

Daar bestaan die gesegde dat filosowe nie - soos wat ander mense dikwels dink - die antwoorde op al die vrae het nie. Hulle stel eerder die vrae oor die te maklike en vanselfsprekende antwoorde! Wat is die heel belangrikste vraag wat 'n filosoof kan stel?

Martin Heidegger is een van die twintigste-eeuse filosowe wat ons aan die grootste, heel belangrikste vraag herinner het toe hy gevra het: "Waarom is daar eintlik iets in plaas van niks?" Met ander woorde: waarom bestaan hierdie werklikheid - insluitende ekself? Hy sê verder dat hierdie vraag veral na vore kom in tye van wanhoop en vertwyfeling, maar ook in tye van verveling wanneer alles so gemeenplasig en alledaags geword het dat dit nie eers meer vir ons saak maak dat daar iets in plaas van niks is nie. Op hulle eie wyse het ander eksistensialistiese denkers (soos Sartre, Camus en Kafka) met hierdie vraag oor die sin van die lewe geworstel en besluit dat dit sinloos is. Ons lewe in 'n absurde wêreld en ons moet dit aanvaar!

1 ' $n$ Gedeelte van sy geleentheidsrede (vierde Stokerlesing van 1999) by die emeritering van prof. Bennie van der Walt as Direkteur van die Instituut vir Reformatoriese studie en professor in Filosofie aan die $\mathrm{PU}$ vir $\mathrm{CHO}$. Potchefstroom, op 12 November 1999

Opgedra aan my kollega en vriend oor baie jare: prof $\mathrm{N}$. Theo van der Merwe 
Ter inleiding wil ek die aandag daarop vestig dat reeds 2500 jaar voor hierdie denkers, die Boek Prediker reeds met hierdie diep vraag gestoe het. Met naakte eerlikheid ondersoek Prediker op empiriese wyse alles waarmee die mensdom hom hier op aarde besig hou. En hy kom tot die logiese gevolgtrekking dat dit alles op niks uitloop - dit is ' $n$ gejaag na wind - sinloos

Hy ondersoek onder andere die volgende weë op soek na sinvolheid:

- wysheid wat die verstand tevrede moet stel (die filosofiese weg);

- plesier wat die liggaam moet bevredig (die hedonistiese weg);

- rykdom wat die beursie volmaak (die materialistiese weg);

- plig teenoor jou medemens wat jou gewete moet sus (die altruisties-etiese weg);

- vroomheid wat die gees bevredig (die godsdienstige weg).

As die skrywer van Prediker egter genadeloos die maskers afpluk, blyk dit dat daar geen doel in dit alles is nie, maar slegs 'n einde - die dood. Daar bestaan geen rede wat dit die moeite werd maak om te lewe nie. Al wat oorbly, is 'n nag van wanhoop.

Volgens Prediker vreet die volgende vyf dinge soos kanker, alle sin en betekenis op:

- alles bly dieselfde en is ewe onbelangrik;

- tyd en geskiedenis is ' $n$ ewigdurende, sikliese, sinlose herhaling,

- die kwaad tas alles aan en bly 'n onoplosbare probleem;

- die dood is die uiteinde;

- ook God is ondeurgrondelik - in die boek Prediker is Hy stil ...

Hierdie boek kon net so goed vandag geskryf gewees het, want - of ons dit erken of nie - die moderne mens se grootste vrees is nie in die eerste plek die dood nie, maar die sinloosheid van die lewe. Hy voel hom vasgevang in die ratwerk van sy eie leë, barre lewensgang, waarin hy soos ' $n$ robot voortsleur. Die bekende historikus Toynbee sê êrens dat van die ongeveer twintig beskawings wat op ons planeet bestaan het, ons hedendaagse Westerse "beskawing" die eerste is wat nie meer die mens se vraag, naamlik waarom hy bestaan, beantwoord nie. Die enigste antwoord op hierdie heel belangrikste vraag wat ons eie tyd kan aanbied, is dat daar geen antwoord is nie!

Ons weet steeds meer oor steeds minder, steeds meer oor klein dingetjies en steeds minder oor die belangrikste dinge. Ons koppe is vol, maar ons harte is leeg. Ons ly aan ' $n$ siekte wat erger is as fisieke dood: die dood van die hart, innerlike leegheid, angs oor die sinloosheid van ons 
B.J. van der Walt

bestaan Te midde van al ons rykdom is ons brandarm; te midde van ongekende mag bly ons magteloos; in ons geluk diep ongelukkig

Hoe kan 'n boek soos Predıker oor die sinloosheid van die lewe enige sin hê? Omdat dıt aan ons dıe wysheid bied om die sinloosheid te kan ontdek. Op Sokratiese wyse, in absolute eerlikheid, stel dit die indringende en onrusbarende vraag: het die lewe - ook my eie - enige sin? Dit ontvlug nie hierdie belangrikste van alle vrae nie. En dit dwing ons om daarop te antwoord. Ons sou kon sê dat Prediker die sentrale vraag stel, terwyl die hele res van die Bybel die antwoord op hierdie vraag gee

Elke geslag en elke mens moet egter vir sy eie tyd en op sy eie wyse hierdie grensvraag beantwoord. Die Skrif dien slegs as ' $n$ voorbeeld van hoe mense en geslagte voor ons daarop geantwoord het. Dit dui egter vir ons 'n duidelike rigting aan waarin ons die antwoord moet soek.

\section{Die drie belangrikste sinvrae gestel en beantwoord}

Hierdie belangrike sinvraag is nie 'n vraag wat net wetenskaplikes stel nie. In werklikheid stel min mense aan universiteite vandag nog hierdie kritieke vraag! Dit is 'n algemeen menslike vraag - een of ander tyd word elke mens daarmee gekonfronteer. Dit mag om baie redes verdring word. Maar omdat alle mense soek na sin - daarsonder kan niemand voluit lewe nie - kan dit nie permanent geignoreer word nie.

Ons grootste probleem is nie dat ons te min weet of onkundig is nie, of dat daar 'n tekort aan wetenswaardighede is nie. Nee, ons grootste bedreiging is ' $n$ tekort aan sin. On-sin, sinloosheid - selfs die sinloosheid van ons deskundigheid - kwel ons. Ons grootste dilemma lê in die sin van dit wat ons doen en nie daarin dat ons nie genoeg het om effektief te wees nie. Inteendeel, ons het te veel om ons mee besig te hou.

Die vraag na die sin van alles is die laaste vraag wat beantwoord moet word ná al ons kundigheid en bedrywigheid. Dit kan ook die heel eerste vraag genoem word, want voordat ons dit nie beantwoord het nie, sal ons ook nie die regte antwoorde op al ons ander vrae kan vind nie. Dit móét dus - een of ander tyd - beantwoord word

Ons kan dit egter nie alleen, uit onsself doen nie. Luister weer wat sê vroeëre en moderne denkers wat hulle met die vraag bemoei het: "Die lewe is ' $n$ verhaal wat deur ' $n$ idioot vertel word - vol klank en passie, maar sonder dat dit enigiets sê" (Shakespeare). "Die lewe is iets wat nie behoort te wees nie" (Schopenhauer). "Daar is net een werklik ernstige filosofiese probleem: selfmoord" (Camus). "Die lewe is vergeefse hartstog" (Sartre). 
Kom ons erken by voorbaat as Christene dat ons nie self $\sin$ aan ons bestaan kan gee nie. God alleen kan dit gee en Hy alleen kan ons sinvraag beantwoord.

Omdat God sin gee en ons dit nie kan maak nie, is dit ook onuitputlik ryk. Ons gaan egter nie hier handel oor al die verskillende soorte sin (ekonomiese, politiese, estetiese, logiese en nog baie meer) nie; ook nie oor die sin van 'n spesifieke menselewe of 'n periode of lewensfase nie. Ons vraag handel oor die sin van die lewe in sy totaliteit. Ons kan dit die ontologiese sinvraag noem

In 'n filosofiese ontologie gaan dit oor die bestaande dinge. 'n Christelike ontologie word aan die Skrif ontleen. Reeds uit die eerste vers van die Bybel leer ons dat God bestaan en dat Hy die hemel en aarde geskep het. In die res van die Skrif word herhaaldelik gesê dat God vir sy skepping sekere gebruiksaanwysings, voorskifte of wette gegee het.

Die drie belangrikste "bestaandes" of werklikhede is dus: (1) God, (2) sy skepping en (3) sy wette vir die skepping. In die lig van hierdie drie werklikhede breek ons die sentrale sinvraag op en stel die volgende drie sinvrae: (1) Waarom? (2) Waarheen? en (3) Waarmee? Waarom bestaan ek? Waarheen is ek op pad? Waarmee hou ek my besig?

\subsection{Waarom?}

Wanneer ons na alles rondom ons kyk, stel ons dikwels in verwondering die reeds genoemde iets-niks-vraag van Heidegger: "Waarom is daar eintlik iets en nie eerder niks nie?"' Met 'n skok word die moontlikheid van die niks hier geopper: hierdie werklikheid - ook ekself - kon net sowel nie bestaan het nie! Waarom bestaan dit dan? Is daar 'n rede voor of is dit ' $n$ grondelose toevalligheid?

Die pragmatisme, tegnokrasie en sciëntisme (wetenskapsverafgoding) wat vandag ons lewens beheers, laat nie tyd of plek om hierdie vraag te beantwoord nie. En die nihiliste, van wie ons 'n paar reeds aangehaal het, aanvaar die sinloosheid van die bestaande. Dit is 'n eerlike, maar terselfdertyd onuithoubare standpunt

\section{Perspektiewe vanuit die Skrif}

God verskaf in sy Woord egter die antwoord op hierdie eerste sinvraag na die waarom van die bestaande. Hy is daar en Hy is die Skepper van hierdie werklikheid. Hy is die "Oorsaak" daarvan.

Mag ons ook 'n tweede keer die waarom-vraag stel: Waarom het Hy die hemel en die aarde geskep? Wat was sy rede daarvoor? Voordat ons dit 
nog gestel het, het Hy dit alreeds in sy Woord beantwoord. Hy het nie geskep net omdat Hy toevallig in die stemming was om iets te doen nie. Sy skeppende Woord "Laat daar wees ..." is ook nie 'n bars bevel nie. Nee, Hy is die Lewende God wat 'n plesier, 'n behae in lewe het. Ook ons lewe is vir Hom 'n vreugdevolle saak. Hy wil hê dat sy genoeë in ons lewe ook vreugde van ons kant sal oproep.

Ons bestaan - en dié van die res van die skepping - het dus 'n grond. Dit is gegrond in die welbehae van God self. As ons dit glo, word ons bestaan verlos van sinloosheid. Dié geloof gee vaste grond onder ons voete: die lewe is daar om in dankbaarheid, vrolik vóór God se aangesig. sáám met Hom te vier!

Die eerste groot sinvraag, die waarom-vraag kan dus alleen in die geloof beantwoord word. Kinderlike geloof. Soos kinders moet ons hierop vertrou. Dit is 'n sekere wete wat ons Vader as 'n groot geskenk gee aan elkeen wat bereid is om weer soos ' $n$ kindjie te word.

Saamgevat is die antwoord op die waarom-vraag oor die ontstaan van alles eenvoudig: God. Hy is daar. Hy verheug Hom ook in sy skepping. In die geloof word ons ontdekkers van hierdie ontsaglike wonder.

\subsection{Waarheen?}

"Waarheen is ons op pad?", is die tweede groot sinvraag. Hierin gaan dit nie oor die rede vir die ontstaan van die lewe nie, maar oor die bestemming van ons lewe, die sentrale doe/ daarvan.

Ons tyd word gekenmerk deur die stel van doelwitte, doeltreffendheid, effektiwiteit, kompetisie en prestasie. Méér geld, méér mag, méér erkenning en prestige dryf ons aan. Ons wil suksesvolie mense wees, net die beste, die wenners van die lewenskompetisie. Dit lyk nie asof die vraag na die sin van dit alles veel kans het om in so 'n milieu gestel te word nie.

Hierdie lewenstyl lewer egter talle wrakke, uitsakkers op. En ook vir die suksesvolles blyk dit nie altyd so 'n salige geluksoord te wees nie. Verder is daar te veel bederwers van die suksesverhaal, byvoorbeeld: Kan 'n mens suksesvol ernstig siek wees? Is die swakheid van die ouderdom 'n prestasie? Wie kan die wedloop teen die dood wen? Kan 'n mens die verwaarlosing van jou vrou, kinders, medemens - ter wille van die dolle gejaag om eie sukses - nog sukses noem? Onherroeplik kom die vraag op: Waarheen was/is ek eintlik op pad in so 'n gebroke wêreld? 


\section{In Skrifbeligting}

Ook in hierdie opsig bevat die Woord van God - ten minste as ons eerlik met die waarheen-vraag geworstel het en die evangelie lees asof ons dit die eerste keer hoor - wonderlike, opwindende nuus. God sal die dreigende onsin oorwin, Hy sal ons waansinnige gejaag op 'n beter spoor bring. In plaas van reisigers op 'n doodlooppad of swerwers na nêrens, wil Hy ons as pelgrims êrens heen lei. Hy lei ons na 'n nuwe aarde toe!

Hierdie belofte moet ons in hoop vasgryp. Dit is nie maar ' $n$ vae verwagting nie, maar ' $n$ vaste sekerheid, 'n bewys van dit wat ons nog nie kan sien nie. Hoe dit sal wees, weet ons nou nog nie. In Openbaring stamel Johannes as hy hieroor profeteer. In negatiewe taal (nie meer siekte, dood, trane ens.) probeer hy die heerlike, positiewe aspekte beskrywe van 'n ontaarde wêreld wat 'n totaal nuwe wêreld sal word.

Hierdie hoop is ook nie passief nie. Dit skep verwagting en gee 'n nuwe visie. Daarom maak dit ons reisvaardig om met die kaart en transport van die nuwe aarde onderweg te gaan.

Saamgevat is die antwoord op die waarheen-vraag eenvoudig: die skepping, nie vernietig nie, maar vernuut; nie 'n bo-aardse geluksoord vir engele nie, maar hierdie aarde. As pelgrims is ons met 'n lied van hoop daarheen op pad!

\subsection{Waarmee?}

Dit is die derde sinvraag: Waarmee hou ons ons hier besig? Hierdie vraag gaan nie, soos die eerste, oor die ontstaan of, soos die tweede, oor die toekoms van ons werklikheid nie, maar oor die bestaande, die hier en die nou. Ons kan sê dit is die pad wat ons nou moet volg, van die verlede na die toekoms. Hoe weet ons dat ons op die regte pad is? Daar is so baie moontlike roetes. Watter norme of waardes moet koers en rigting gee aan ons lewensreis?

Ook dit is ' $n$ uiters aktuele vraag in ons tyd en land. Daar word vandag van morele bankrotskap gepraat, van die wet van die oerwoud. Groot verwarring, selfs vertwyfeling, bestaan oor wat reg en verkeerd, goed en sleg, mooi en lelik is. As gevolg van die feit dat die moderne mens dinge wat aan God se wette onderworpe is, self tot wette verhef het, heers normatiewe sinisme. Net soos die nihilisme dit laat vaar het om die waarom-vraag te stel, is hierdie sinisme onverskillig oor die vraag, naamlik wat reg en verkeerd is - "everything goes" Net soos in die geval van die nihilisme, is ook die sinisme egter nie $n$ uithoubare, leefbare standpunt nie. Sonder 'n antwoord op die waarmee-vraag is ons lewe koersloos en loop dit op die rotse 
B.J. van der Walt

Die diepste rede waarom die waarheen- en die waarmee-vraag deur baie nie beantwoord kan word nie, is omdat die heel eerste sinvraag (die waarom-vraag) nie reg beantwoord is nie. As God nie bestaan nie, is die ontstaan van die wêreld onverklaarbaar, bestaan daar geen toekoms nie en bly dit ook ' $n$ raaisel hoe ons in die hede ons lewens moet inrig.

\section{Hoe die Skrif dié sinvraag aanspreek}

Ook in hierdie geval kom die Woord van God ons met die oplossing tegemoet. Dit gee aan ons duidelike pad- of reisreëls wat koers en rigting bied. Die antwoord op die twee vorige vrae was geloof en hoop. Nou is dit liefde.

Die liefde wat God van ons vra, en wat in 1 Korintiërs 13 beskryf word, is 'n liefde wat gee. Dit word saamgevat in die woorde: "Wie sy lewe wil behou, sal dit verloor. Maar wie bereid is om dit te verloor, sal dit terugvind" (Matt. 17:25). Wat 'n wonderlike boekhoustelsel waar verlies wins oplewer! Vir ons wat soveel moontlik wil hê, is dit waansin. Die Bybel noem dit egter die logika van die (ryk) dwaas

Behalwe om te besit, wil ons ook graag gesien word. Die Woord van God sê egter: "Die eerstes sal laaste wees".

Ons wil verder graag gedien word, maar volgens die evangelie moet ons Christus navolg en Hy het nie gekom om gedien te word nie maar om te dien, sy lewe vir ons te gee (Matt. 20:25-28). Paulus herinner ons daaraan dat Christus, wat God was, Homself verneder het deur die gestalte van 'n slaaf aan te neem. Dieselfde gesindheid moet ook in ons wees! (Fil. 2:5-7)

Ware godsdiens is dus nie die goedkoop vroomheid wat ons vandag dikwels teëkom nie. Nee, dit is selfverloënende, onvoorwaardelike diensbaarheid. Dit beteken om geheel en al - as dankbare offer - vir God beskikbaar te wees. Dit beteken om ons lewe aan Hom oor te gee, dit letterlik weg te gee.

Ware godsdiens is ook naastediens. Dit beteken bewoëndheid, medelye, barmhartigheid met eensames, hongeriges, werkloses, gebrokenes, verontregtes, onderdruktes en siekes. Nie omdat ons iets terug verwag nie Soos God se liefde aan ons, is hierdie liefde ex gratia, gratis. Is onbewoënheid, harteloosheid nie die grootste hartseer van ons tyd nie?

Nie sukses nie, maar liefde - God se sentrale gebod - is die norm vir ons lewe. As ons werklik 'n effektiewe, geslaagde, doeltreffende, funksionele, bevredigende - en watter ander modewoorde daar nog mag 
wees - lewe wil voer, is die liefde tot God en ons medemens die enigste antwoord.

Net soos die geloof en die hoop, laat die liefde ons nie agteroorsit en op ons louere rus nie. Behalwe dat dit ons lewe 'n vaste koers gee, maak dit ons ontsteld oor almal wat God se "gebruiksaanwysings" vir die lewe in die wind slaan: ontrou in die huwelik, ongeregtigheid op politieke terrein vermorsing van skaars goedere, besoedeling van die natuur. Die liefde maak van ons hervormers, mense wat nooit met die bestaande vrede kan maak nie.

Saamgevat is die antwoord op die derde sinvraag, die waarmee-vraag, eenvoudig: God se wet. Dit roep ons op om in selfvergetende liefde te dien. As ons dit doen, loop ons lewe oor van sinvolheid!

Wat, nee Wie, is die geheim agter hierdie drie antwoorde? Dit is Christus, wat die bitter beker van hierdie drie kwellende sinvrae tot die droesem toe gedrink het. Hy is deur die duiwel versoek om selfmoord te pleeg. Hy het in die hele skepping geen plek gevind om sy kop neer te lê nie. Hy het alleen aan die kruis, van die liefde van God en mens verstote, gehang, sodat Hy moes uitroep: "My God, my God, waarom het U my verlaat?" Veel ernstiger en dieper as enige mens het Hy die waaroms van die lewe deurworstel.

Maar omdat Hy nie net mens nie, maar ook God was, het Hy dié Bron van elke soort lewensin geword. Sy Gees gee aan ons die geloof, hoop en liefde om dié sin ons eie te maak en uit te leef.

\subsection{Samevatting}

Alles tot sover, kan skematies in die volgende vier punte saamgevat word:

- Die drie belangrikste werklikhede is:

- God

- Skepping

- Wet

- Die drie belangrikste sinvrae wat daarby aansluit, is:

- Waarom bestaan iets/ons? Die ontstaans-/oorsprongsvraag verlede

- Waarheen is dit /ons op pad? Die bestemmingsvraag - toekoms

- Waarmee kan ons koers hou? Die normatiewe vraag - hede

- Die Bybelse antwoorde op hierdie drie sinvrae is: 
- God, die Skepper: Hy formeer dit, as gevolg van sy welbehae het dit ontstaan.

- God, die Verlosser: as gevolg van Christus se versoening het dit 'n toekoms, ten spyte van die deformasie na die val.

- God, die Heilige Gees: as gevolg van sy openbaring kan dit hier en nou rigting/koers hê, is reformasie moontlik.

- Ons antwoord daarop moet wees.

- Geloof maak ons ontdekkers van 'n ontsaglike wonder: die lewe het ontstaan omdat dit God behaag het en sodat ons dit dankbaar voor sy aangesig sal vier.

- Hoop maak ons pelgrims op pad na 'n nuwe aarde, omdat Christus se versoeningswerk alles sal vernuwe.

- Liefde maak van ons selfvergetende diensknegte en diensmaagde, wat onder leiding van en in die krag van die Heilige Gees volgens God se gebooie lewe.

\section{3. 'n Toespitsing van die sinvraag op ons verhouding tot God se skepping}

Sin is ten diepste dus nie iets wat ons self kan maak of skep nie - die dwaling van alle ideologieë. Dit is iets wat God uit genade as gawe skenk wanneer ons God se opdrag beantwoord, naamlik om Hom volgens sy gebooie te dien. Dit moet ons in hierdie skepping doen.

Ek wil slegs een faset van ' $n$ sinvolle bestaan voor die aangesig van God aan die orde stel. Dit is ons verantwoordelikheid teenoor wat ek breedweg as die "natuur" aandui. Met "natuur" bedoel ek dié aspek van God se skepping waar die ingrype van die mens nog nie heeltemal die oorspronklike karakter daarvan verander het nie. In die meeste gevalle het ons vandag nie meer met egte natuur te make nie, maar in ' $n$ mindere of meerdere mate met 'n gekultiveerde natuur. (Selfs 'n wildpark met sy heinings, paaie en waterpunte is nie meer suiwer "natuur" nie). Ek veroorloof my egter die vryheid om "natuur" en "skepping" soms ook as sinonieme te gebruik.

My sentrale boodskap sal daarop neerkom dat ons die natuur nie net sal beheer en gebruik nie, maar dit ook sal beskerm, waardeer, geniet en boweal God daarvoor sal prys. Kernagtig gestel, is die sin van ons bestaan as mense dat ons iede is van die groot skeppingskoor tot eer van God. 
Om hieroor met $u$ te kan gesels, bied aan my die geleentheid om (1) ' $n$ dowwe kol in my eie lewensvisie duideliker uit te bou en (2) om 'n prinsipiële regverdiging te bied vir my groot liefde om die natuur as 't ware per pedes apostolorum, al stappende te ontdek, geniet en waardeer

In hierdie gedeelte let ons op die volgende hoofpunte: (1) die gangbare houding van baie Christene teenoor die natuur; (2) die diepere, lewensbeskoulike oorsake daarvoor; (3) wat die Bybel werklik oor God se skepping, sy en ons verhouding daarteenoor leer en (4) enkele praktiese wenke om groter waardering vir en vreugde in God se skepping te bevorder.

Ter afsluiting van my voordrag sal ek weer na die breë sinvraag terugkeer deur dit toe te pas op my eie taak aan die PUK: Wat was die sin van my werk by die IRS en in die Departement Filosofie?

\section{Gangbare Christelike houdings teenoor die natuur}

Afhangende van hul teologiese oriëntasie, vind ons drie houdings by baie Christene, waarvan ek die eerste twee nou verduidelik.

- Die een groep is geinteresseerd in hoe die skepping ontstaan het Hulle is dadelik omgekrap wanneer iemand bloot die suggestie sou maak dat die aarde, soos ons dit ken, op evolusionêre wyse oor miljoene jare tot stand gekom het. Oor die toestand van die bestaande skepping bekommer hulle hulle egter weinig. Hulle raak byvoorbeeld hewig ontsteld as iemand evolusionisties oor die ontstaan van die skepping sou dink, maar hulle bekommer hulle glad nie oor 'n seldsame plant, voël of soogdier wat op die gevaarlys van moontlike uitwissing is nie. Hulle verroer nie ' $n$ vinger as 'n seldsame spesie se habitat vernietig sou word deur industriële ontwikkeling, mynbouaktiwiteite, 'n nuwe woongebied of ' $n$ nuwe gholfbaan nie! 'n Mens sou hulle kon vergelyk met 'n ouerpaar wat vreeslik opgewonde was by die geboorte van hulle kind en heeldag praat oor die wonderlike gawe wat hulle van die Here ontvang het, terwyl hulle vergeet om die kind te versorg!

- Die tweede groep Christene lê weer alle klem op die Bybelse profesieë oor die eindbestemming van die skepping; hoe die huidige skepping sal brand en vergaan, voordat die voleinding aanbreek. Hulle argumenteer byvoorbeeld dat, as God tog die skepping, soos dit tans daar uitsien, in die eindtyd deur vuur sal laat vergaan, dit nie die moeite werd is om dit nou ten alle koste te probeer beskerm nie.

Nie een van hierdie twee groepe is veel geinteresseerd in die ontwikkeling en toestand van die bestaande skepping nie of is slegs in 
enkele aspekte daarvan geïnteresserd: (1) Hulle waardeer dit nie, (2) vind weinig of geen vreugde daarin nie en (3) doen ook nie moeite om dit te beskerm nie

Dit is duidelik dat daar ' $n$ verband is tussen waardeer, geniet en bewaar As 'n mens God se skepping nie waardeer nie, sal jy dit nie geniet nie sal jy ook nie die moeite doen om dit te bewaar nie. Omgekeerd: as 'n mens dit nie bewaar nie, sal daar uiteindelik ook nie meer veel oor wees om te waardeer en te geniet nie!

Volgens die Skrif - soos nog sal blyk - is ons betrokkenheid by God se skepping (om dit te beheer, te beskerm en te geniet) ' $n$ inherente deel van ons Christenskap. Die Bybel bevat dan ook veel meer besonderhede oor ons taak in die bestaande skepping as oor die ontstaan of die vergaan daarvan.

Een van die skrywers wat ek geraadpleeg het, maak selfs die volgende opmerking: Hoe meer gesag Christene aan die Skrif toeken, hoe minder omgewingsbewus is hulle. Omgekeerd is liberale Christene wat nie so Bybelgetrou dink en leef nie, meestal veel meer omgewingsbewus. Lê die fout dan by die Bybel?

Soos reeds vermeld, kan die rede egter nie wees dat die Skrif niks of weinig oor ons ekologiese verantwoordelikheid sê nie. Die rede moet dus by ons teologiese uitgangspunte en in ons lewensvisie lê. Dit verhinder dat ons belangrike Skrifgedeeltes raaksien of, as ons hulle wel raaklees, heeltemal verkeerd interpreteer.

Heel waarskynlik speel ons Westerse kultuur en lewensvisie hierin 'n belangrike rol. Hoewel daar in sommige kringe vandag groter natuurbewustheid voorkom, word die natuur deur die meeste nog steeds beskou as ' $n$ objek wat alleen van belang is in soverre dit tot nut van die mens - vir sy behoeftes en begeertes - gebruik kan word. Ons moderne tegnologie het ons verder van die natuur vervreem. Ons lewe in 'n kunsmatige wêreld. Mensgemaakte nabootsings van die natuur (vgl. die "Lost City" by Sun City) vervang die werklikheid, soos plastiekblomme vars blomme. Ons is meer beindruk met wat ' $n$ mikroskyfie kan doen as oor die wonder van 'n klein saadjie waaruit 'n groot boom ontwikkel. Ons word geboei deur alles wat die internet ons kan bied, maar raak verveeld wanneer ons alleen in die natuur moet vertoef.

Ons laat hier egter die Westerse invloed daar, ten einde die vraag te probeer beantwoord waarom baie Christene so ' $n$ traak-my-nieagtige en selfs negatiewe houding teenoor God se skepping toon. Wat is die diepste oorsake daarvan? 


\section{Die diepere, lewensbeskoulike oorsake vir sulke houdings}

Myns insiens speel die volgende faktore 'n belangrike rol:

\subsection{Filosofies-ontologiese uitgangspunte}

Hoe ons die verhouding tussen God en sy skepping beskou, bepaal ook hoe ons self teenoor die skepping staan. Anders gestel: sonder 'n Bybels-filosofiese ontologie of synsleer beland ons op dwaalweë.

Twee belangrike ontologiese posisies wat in die Westerse kultuur na vore gekom het, is die panteisme en die deisme.

- Die panteïsme leer dat daar nie onderskeid tussen die Goddelike en die kreatuurlike bestaan nie - die skepping self is Goddelik. Baie van die ekologies-bewuste mense huldig so ' $n$ beskouing.

Selfs Christene swig voor die versoeking, sonder om te besef dat panteisme maar net 'n "vriendelike" soort ateĩsme is: as alles God(delik) is, is niks werklik God nie! Of hulle dink panenteisties, wat beteken dat die heelal 'n uitvloeisel van God is.

Net soos in die geval van die animisme (die lewensvisie van tradisionele Afrikane wat glo dat alles besield is), lei die panteisme en panenteïsme tot 'n verering van die skepping self, in plaas van aanbidding van die Skepper daarvan. Terwyl die deïsme (vgl. hierna) tot uitbuiting van die skepping lei, is die gevaar van die panteisme 'n verromantisering daarvan.

- Die tweede ontologiese visie is dié van die deïsme. Terwyl die panteisme God en skepping nie onderskei nie, maar identifiseer, word hulle in die deïsme van mekaar geskei. God kon nog die skepping in aansyn geroep het, maar omdat Hy so totaal anders as die skepping is, is Hy tans ' $n$ Godheid wat ver weg is, 'n Godheid wat nie eintlik daarin belangstel nie en slegs in krisissituasies sal "ingryp", omdat die skepping normaalweg sonder Hom kan regkom.

Hierdie standpunt kom ook in die praktyk baie algemeen onder Christene voor - al sou hulle dit in teorie (bv. in hul belydenis of teologie) hewig ontken dat hulle deïsties dink. Lynn White slaan in sy berugte artikel "The historical roots of our ecological crisis" (1967) die spyker op die kop wanneer hy sê dat die Christendom in 'n groot mate medeverantwoordelik is vir die "verkragting" van die aarde, omdat hulle glo dat God so transendent en verwyderd van die fisiese dinge is dat Hy nie daarin belangstel nie. 


\section{Wat is die korrekte standpunt?}

Die Skrif leer dat God tegelykertyd naby sy skepping is, maar ook anders as, onderskeie van die skepping is; daar is 'n verband, maar ook 'n verskil. Hoe moet ons dit verstaan? Ons kan dit nie verstaan nie, omdat die ruimtelike faset iets van die skepping is en nie op God van toepassing nie - terwyl ons net in ruimtelike terme oor Hom kan dink! Die naaste wat ons aan 'n oplossing kan kom, is om terminologies duideliker te onderskei: God is religieus gesproke in sy skepping, daagliks daarby betrokke, maar ontologies beskou, is Hy totaal anders as sy skepping. Al twee hierdie perspektiewe moet gelyktydig gehandhaaf word om die dwaling van sowel die panteïsme as deîsme te kan vermy en die verhouding tussen God en sy skepping te behou. Dit is egter nie net die deisme wat hierdie verhouding ontken nie. As God en skepping geïdentifiseer word (soos in die geval van die panteïsme), dan bestaan daar ook nie meer 'n verhouding nie!

Hierdie verhouding is baie intiemer as wat ons ons ooit kan indink. In plaas van om Hom êrens in die skepping te soek, moet eerder in die teenoorgestelde rigting gedink word: Die skepping bestaan in Hom, dit word deur sy ewige krag gedra.

Die Bybelse visie kan (in aansluiting by ons vorige onderskeid tussen die drie belangrikste werklikhede) diagrammaties soos volg verduidelik word:

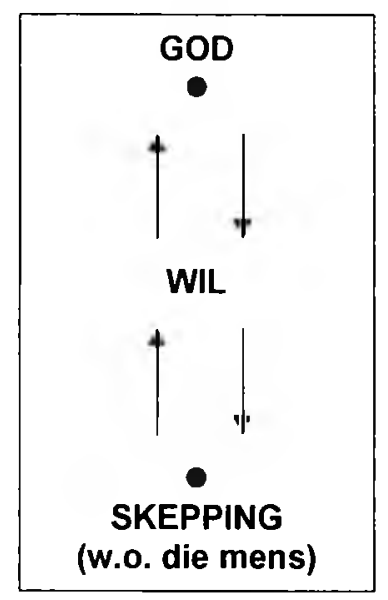

Hieruit blyk dat (1) God in verhouding tot die skepping staan; (2) die mens en die res van die skepping in verhouding tot God staan; (3) dat die mens God in die skepping moet dien en (4) dat hy dit volgens God se 
wil moet doen. (5) Om God se wil te ken, skenk God sy openbaring in verskillende vorme: in woordelose vorm in sy skeppingsopenbaring, in 'n talige vorm in sy Skrifwoord en uiteindelik as vleesgeworde Woord in sy eie Seun, wat God gedien het soos ons Hom behoort te dien.

Hiermee is voldoende gesê oor die diepere ontologiese vertrekpunte. Die volgende oorsake vir die min belangstelling onder Christene in die natuur, noem ek net kortliks.

\subsection{Eensydige klem op verlossing}

Die heilsgeskiedenis loop vanaf die skepping oor die sondeval na die verlossing en uiteindelik die voleinding. Verskillende soorte Christendom en teologieë lê eensydig die klem op net een van hierdie drie hoofmomente. (Sekere vorme van die Calvinisme was byvoorbeeld geneig om die sondeval sterk te beklemtoon.) Die Bybelse boodskap word egter "omraam" deur skepping en herskepping. Die merkwaardige is egter dat in ons gangbare Christelike lewensvisies die skepping deur die verlossing oorskadu word. Eensydige klem word op verlossing gelê, sodat die skepping byna vergeet word. Intussen word nie besef dat dit die skepping is wat verlos moet word nie. Verlossing hang nie in die lug nie! God wil hierdie wêreld verlos. Hy het dit so lief gehad dat Hy sy enigste Seun daarvoor laat sterf het!

Ons spandeer soveel tyd om God te loof vir die kruis van Christus, dat ons vergeet om Hom te prys vir die skepping wat deur die kruis verlos word! Verlossing is immers nie 'n doel op sigself nie, maar ' $n$ middel waardeur die mens God weer kan liefhê en in sy skepping kan dien.

\section{3 'n Antroposentriese beskouing van skepping, sondeval en verlossing}

- Eerstens word die skeppingsverhaal antroposentries of mensgesentreerd gelees. Dit loop uit op 'n klimaks: die skepping van die mens as die kroon van die skepping in wie se diens al die ander skepsele moet staan.

- In die tweede plek word ook die sondeval so gelees. Sonde is net iets wat teen God en die medemens gedoen word. Die sonde teenoor God (die eerste vier gebooie) sou van religieuse aard wees en dié teenoor die medemens (die laaste ses gebooie), van morele aard. Van ekologiese sonde (ook 'n ongehoorsaamheid aan God se wil) ten opsigte van die skepping (stof, plant en dier) word selde, indien ooit, gehoor. Ons spandeer soveel tyd om godsdienstig en eties reg te leef, dat ons 
totaal vergeet dat ons ook ekologies reg moet leef - dit is ook ' $n$ deel van ons Gods-diens

- In die derde plek word ook verlossing antroposentries gekleur: dit gaan oor die mens se ewige saligheid. Christus het vir mense gesterf en nie vir die ganse skepping nie. Hy is nie 'n kosmiese Redder nie, maar slegs 'n Verlosser van mense!

Daar word verder selde daarvan melding gemaak dat die sondeval (deur die mens veroorsaak) ook die res van die skepping aangetas het - soos wat die gedeelte oor die sugtende skepping in Romeine 8:19-22 duidelik leer. Die ekologiese gevolge van die sondeval word totaal oorskadu deur die groot klem op die religieuse en morele gevolge daarvan vir die mens!

\section{4 'n Verspiritualiseerde verlossingsidee}

Die Bybelse soteriologie word gewoonlik nog verder vereng tot die verlossing van die mens se dierbare siel, die belangrikste "deel" van sy bestaan. Sy "materiële deel" (die liggaam) is nie belangrik nie: Daar word by voorkeur gepraat van die hemel - in plaas van die beloofde nuwe aarde. Dikwels word dit in bepaalde tradisies ook so voorgestel dat ons in die hiernamaals, geklee in wit klere met engelvlerke, op die wolke sal sweef en goue harpe sal bespeel.

Soos ons nog sal sien, is die Bybelse eskatologiese hoop veel aardser en veel "groener" as so 'n soort bowêreldse bestaan.

\section{5 'n Verkeerde idee van die mens se plek as heerser oor die skepping}

Die laaste foutiewe uitgangspunt is ten opsigte van God se opdrag aan die mens om die skepping te bewerk en daaroor te heers (Gen. 1:28b en ook Gen. 9:1-4). Soos reeds gesê, beteken dit volgens baie Christene dat die res van die skepping alleen bestaan om beheers te word ter wille van die mens, sy persoonlike nut, voordeel en begeertes. Die mens se heerskappy oor die skepping geskied in ooreenstemming hiermee. Stof, plant en dier moet hom dien, in plaas van - soos ons nog sal sien - dat die mens se gesag oor die skepping diens aan die ander lewende wesens beteken!

Saamgevat het ons tot sover bevind dat baie mense - Christene ingesluit - die natuur nie werklik geniet, respekteer, beskerm en die Skepper daarvoor prys nie. Die redes daarvoor moet nie gesoek word in die Skrif nie, maar in verkeerde teologiese en lewensbeskoulike uitgangspunte wat die wyse waarop die Bybel gelees word, beinvloed. Vyf sulke 
verkeerde vertrekpunte is genoem. Ons is nou gereed om te luister na wat die Bybel werklik oor hierdie belangrike aangeleentheid openbaar.

\section{Perspektiewe uif die Skrif}

Ons let agtereenvolgens op (1) God se verhouding tot sy skepping; (2) die skepping se verhouding tot God en (3) die plek van die mens in hierdie verhouding.

Ter inleiding vestig ek slegs die aandag daarop dat ons die skeppingstema in die Skrif nie net in Genesis 1 en 2 of net in die Ou Testament vind nie. Ons vind dit ook in byvoorbeeld die Evangelie van Johannes (1:1-3), Kolossense (1:16-17), Hebreërs $(1: 2,10)$ en in Openbaring (4: 11). Uiteindelik sluit die Skrif af met die nuwe hemel en aarde (kyk Op. 21 en 22) - wat weer aan die skepping aan die begin herinner. Ook ons ekumeniese belydenisskrifte (die Apostoliese Geloofsbelydenis en die Geloofsbelydenis van Nicéa) begin soos volg: "Ek glo in God die Vader, die Almagtige, die Skepper van hemel en aarde ...".

Dit is hoog tyd dat die skepping self weer sy regmatige plek in ons Christelike lewensvisies terugvind. A.M. Wolters vat die essensie van 'n Bybels-Reformatoriese lewensvisie saam in die titel van sy pragboek: Die skepping herwin (oorspronklik in Engels: Creation regained).

Ons let nou op die eerste hoofpunt:

\subsection{God se verhouding tot sy skepping}

Ons het reeds gesien dat, hoewel God ontologies lemand totaal anders as sy skepping is en dus duidelik daarvan onderskei moet word (niks in die skepping is Goddelik nie), Hy in religieuse sin altyd naby sy skepping, intiem daarby betrokke is. Dit blyk duidelik uit onder andere die volgende

- God self is die Skepper van die heelal, wat die aarde insluit waarop ons woon. Heel aan die begin van die Bybel lees ons reeds: "In die begin het God die hemel en die aarde geskep" (Gen. 1:1). Op die vraag waarom Hy dit gedoen het, sal ons moeilik ' $n$ antwoord kan gee, behalwe wat die Skrif self daaroor sê. Soos ons reeds gesien het, was dit vir Hom ' $n$ vreugde om alles tot stand te bring.

- Alles was goed, baie goed. Telkens in die skeppingsverhaal (Gen. 1) waarin vertel word hoe die aarde met sy bewoners ontstaan het, word dit soos 'n refrein herhaal: "En God het gesien dit is goed". Aan die einde van die skeppingsverhaal (Gen. 1:20) staan daar: "Toe het God gekyk na alles wat Hy gemaak het en dit was baie goed" (kursivering - BJvdW). 
B.J. van der Walt

Volgens sekere Skrifverklaarders moet ons hierdie "goed" nie bloot as moreel goed/reg verstaan nie, maar in 'n verskeidenheid betekenisse, afhangende van dit waarna verwys word. Dit kan byvoorbeeld ook esteties goed of mooi beteken.

- "... en God het hulle geseën" geld nie net vir die mense (Gen. 1:28) nie, maar nog voor die mense, reeds vir voëls, visse en diere (Gen. 1:22). Lank voordat God die eerste mense op die aarde laat woon het val die hoogste eer en voorreg - sy Goddelike seen - die gevinde en gevleuelde wesens ten deel! As Christus (met sy hemelvaart) sy deurboorde hande seënend ophef, seen $\mathrm{Hy}$ dus nie net sy dissipels nie, maar die hele skepping waarvoor Hy sy lewe gegee het.

- "... en Hy het gerus na al die werk wat Hy gedoen hel". In my katkisasiedae het die dominee my al geleer dat dit nie beteken dat God van toe af niks gedoen het nie. Hy bly as Onderhouer aktief betrokke by sy skepping. Wat ek nie geleer het nie, is dat God nie gerus het omdat $\mathrm{Hy}$ moeg was nie, maar om as 't ware te kon terugsit en te geniet, om vreugde te kon hè in dit wat Hy geskep het. Hy het sy hele skepping nie net oneindig lief nie, maar het ook 'n Goddelike behae daarin! Die gebed van Psalm 104:31 lui: "Mag die werk van die Here Hom vreugde verskaf!"

Hoewel God na die sondeval teleurgestel is in sy skepping - voor die sondvloed word daar uitdruklik gesê dat God bedroef was dat Hy die mens gemaak het (Gen. 6:6-7) - gee Hy alreeds 'n belofte van herstel (Gen. 3:15 en 9:11), sodat sy droefheid nie vir altyd sou duur nie.

- Elke skepsel het waarde vir God. Terwyl baie mense dink dat minerale, plante en diere net waarde het in die mate wat hulle vir die mens nuttig is, is dit uit die Skrif duidelik dat hulle op sigself vir God inherente waarde besit, afgesien van wat hulle vir die mens kan beteken. Hierna sal ek verduidelik waarom dit die geval is. Ek wil nou eers 'n paar voorbeelde noem van God se bemoeienis met, sorg vir en besorgdheid oor sy niemenslike skepsele, soos dit op verskillende plekke in sy Woord na vore kom.

- God se besorgdheid oor sy niemenslike skepsele. Ek noem slegs die volgende voorbeelde:

- Die land self moes elke sewende jaar (die Sabbatsjaar) kans kry om te rus, sodat die grond nie uitgeput raak nie (vgl. Eks. 23:10 en Lev. 25:1-7).

- Die plantelewe moes beskerm word. In Deuteronomium 20:19 verbied die Here byvoorbeeld die volk om die bome rondom 'n stad 
wat hulle beleër af te kap, "want die bome op die land is nie mense dat jy teen hulle moet veg nie"!

- Die voëllewe moet met respek behandel word (vgl. Deut. 22:6-7)

- Dit geld ook vir die dierelewe. Dit is opmerklik dat God nie net die diere in Noag se ark beskerm nie. Hy sluit hulle ook uitdruklik in in die verbond wat Hy na die sondvloed met Noag en sy mense sluit (Gen. 9:8-11)! Sy Sabbatswetgewing sluit in dat die diere ook op dié dag moet rus (Eks. 20:10). Volgens Jona 4:11 is God nie net besorgd oor die 120000 mense nie, maar ook oor al die diere in die stad Nineve!

Saamgevat het "dooie" grond, "stom" plante en "verstandlose" diere vir God self groter waarde as wat ons as mense gewoonlik aan hulle toeken. Hulle het nie alleen via die mens betekenis nie. Die mens mag ook nie volgens menslike maatstawwe besluit dat sommige van God se skepsele van minder belang is nie. Twee voorbeelde: Bome bestaan nie net om hout vir brandstof, meubels, papier of ander menslike doeleindes te lewer nie. En hoenders mag nie (in die geval van braaikuikens wat hulle hele lewe in beknopte batterye deurbring) gedegradeer word tot ' $n$ stuk witvleis met 'n paar lastige vere daaraan nie.

Die modaliteitsleer van die Reformatoriese filosofie en die onderskeid tussen objeks- en subjeksfunksies kan ons ook help om te besef hoe "ryk" gewone fisiese dinge is. Papier byvoorbeeld (wat van hout gemaak is) is wel iets fisies, maar dit kan verskillende objeksfunksies in die menslike sfeer vervul, byvoorbeeld ' $n$ estetiese (in die geval van ' $n$ skildery) of religieuse (in die geval van 'n Bybel of ' $n$ liedereboek op papier gedruk)

Let egter daarop dat God in al hierdie gevalle nie die gebruik nie, maar wel die misbruik van grond, plante, voëls en diere verbied.

Tot sover het ons gehandel oor die Bybelse visie op God se verhouding tot sy skepping. Ons tweede hoofpunt handel oor die omgekeerde:

\subsection{Die skepping se verhouding tot God}

God toon nie net vreugde, liefde en besorgdheid teenoor sy skepsele nie. Die skepsele moet ook liefde teenoor God toon. Deur God se Woord het alles tot stand gekom. Die sin van die skepping is om daarop te antwoord.

Myns insiens was dit ' $n$ besondere bydrae van een van my leermeesters, prof. H.G. Stoker, dat hy geleer het dat nie net die mens in 'n verhouding tot God staan, wat hy as 'n religieuse verhouding aangedui het nie. Ook 
die res van die skepping (stof, plant en dier) staan in verhouding tot God Dit het hy die teale verhouding genoem.

\section{Die lied van die skepping}

Binne ons eng antroposentriese lewensvisie dink ons God word net geprys wanneer volwassenes lofliedere vir Hom in die kerk sing. Die verrassende in die Bybel is egter dat nie net kinders en selfs suigelinge nie (Ps. 8:3), maar ook die natuur self God onophoudelik prys. Laasgenoemde sou ons die "lied" of die "koor" van die skepping kon noem, hoewel dit nie ' $n$ lied in menslike taal en woorde en met menslike melodieë is nie. Psalm 19:4 noem dit 'n lied "sonder spraak en sonder woorde".

Op verskillende plekke in die Skrif lees ons van die woestyn wat sing, berge en heuwels wat jubel en juig, bome wat hande klap en nog meer soortgelyke uitdrukkings (vlg. bv. Jes. 35:1, 2 en 55:12). Dikwels word dit as antropomorfe metafore of beeldspraak afgemaak. Dit sou gewoon digterlike taal wees wat nie letterlik opgeneem moet word nie. Volgens meer resente kommentare mag dit egter nie so eensydig verstaan word nie.

Psalm 148 is ' $n$ duidelike voorbeeld waar die digter as 't ware as die koorleier optree en die ganse skepping oproep om God te loof. Die "prys die Here" aan die begin van die Psalm is die vertaling van die oorspronklike Hebreeuse halleluja. Dit is nie ' $n$ emosionele uitroep of indikatief nie, maar ' $n$ imperatief, ' $n$ bevel, ' $n$ oproep om by die kosmiese lied tot eer van God aan te sluit. Dit sluit nie net die hemel en sy bewoners en die hemelliggame in nie, maar ook die aardse skepping en al sy bewoners (v. 7-10). Eers in vers 11 en 12 word mense opgeroep om in die kosmiese koor te sing.

Waarom moet ons die oproep tot die engele en die mense letterlik neem, terwyl ons die voorafgaande gedeelte as figuurlike taal beskou? As ons as mense die woordelose skeppingskoor van stof, plant en dier nie kan hoor nie, beteken dit nie dat dit nie 'n werklikheid is nie; of dat God dit nie kan hoor of waardeer nie!

Uit ander natuurgedeeltes (soos bv. Job 39 en 40) blyk dit ook duidelik dat wilde diere (bv. die seekoeie), wat destyds vir die mens van geen nut was nie, aan God self vreugde verskaf. 


\section{Die skeppingslied mag nie gedemp word nie}

Net soos wat 'n simfonieorkes waarin een instrument ontbreek, of ' $n$ koor wat een stem mis, nie volledig is nie, is ook hierdie kosmiese koor onvolledig as een grondstof opgebruik, een stroom opgedroog, een plant of dier uitgesterf het. Selfs al sou net hulle getalle afneem, verminder die lof aan hulle Skepper. Hieruit blyk duidelik dat ons nie maar ongeërg kan toekyk hoe die natuur uitgebuit, besoedel en vernietig word nie.

\section{Die lied van die sugtende skepping}

Dit bring ons by ' $n$ ander kant van hierdie lied van die skepping waaroor Paulus in Romeine 8:19-22 handel. Behalwe 'n blye loflied, is dit dikwels - as gevolg van die mens se ongehoorsaamheid aan God - ook 'n hartseer treurlied. Hoor ons as mense nog hierdie hartseer tone uit die res van die skepping of het ons net ore en oè vir menslike pyn en lyding?

Paulus gebruik heel gepas die beeld dat die skepping in barensnood verkeer (v. 22) of, soos die Nuwe Vertaling lees, in "die pyne van verwagting". 'n Vrou wat geboorte gee, ervaar tegelyk vreugde en pyn. Nroeër was dit baie moeiliker om geboorte te skenk - dit was soms 'n stryd tussen lewe en dood.)

Omdat God Hom aan sy belofte van 'n nuwe skepping hou, kan die skepping egter met "reikhalsende verlange" (OV) of met "gespanne verwagting" (NV van v. 19) daarna uitsien. Die Ou Vertaling is 'n beter weergawe van die oorspronklike Griekse woord apokaradokia, wat letterlik beteken "om jou nek te rek", ten einde beter te kan sien. Die skepping staan as 't ware op sy tone om te kan sien wanneer die lied van die sugtende skepping in 'n onvermengde lied van suiwer blydskap teenoor God sal verander! Hierdie hoop van die sugtende skepping klop in elke singende voël, kabbelende stroom, oopgaande lentebloeisel, geboorte van 'n nuwe dag of ' $n$ lewende wese, in die gloed van 'n veraf ster.

Ondersteun ons as mense hierdie hoopvolle verwagting of verdiep ons eerder die pyn en lyding van 'n sugtende skepping?

\section{'n Aardse toekomsverwagting}

Dit waarna die skepping uitsien, is nie iets vaags esoteries, onwêrelds of geesteliks nie. Ook hieroor sê die Skrif heelwat - al moet ons besef dat die herbore skepping veel ryker en wonderliker sal wees as in ons wildste drome en wat die Bybelse profesieë daaroor onder woorde kon bring. 
Weer eens kan ek slegs enkele flitse uit die ontsaglike rykdom van die Bybel gee en hierdie keer kom dit uit die boek van die profeet Jesaja.

Reeds in Jesaja 2:4 word van vrede tussen die mense gepraat: Van swaarde word ploegskare gemaak en van spiese snoeiskêre - mense sal nie meer leer om oorlog te maak nie!

In Jesaja 35 word die barre, onvrugbare woestyn gebruik as 'n simbool van die aarde wat onder God se vloek lê, die woonplek van die bose. Hierdie hoofstuk profeteer egter van 'n woestyn wat oortrek is van water, sodat affodille daar sal bloei. Op die eertydse verskroeide aarde sal gras, riet en biesies groei, lammers sal daar bokspring, daar sal geen roofdiere meer wees nie, blindes sal sien en dowes sal hoor.

In Jesaja 55:12-13 word iets soortgelyks gesê. Berge en heuwels sal jubel en juig; die bome sal van vreugde hande klap; in die plek van die doringbos sal 'n sipres opskiet en in die plek van 'n dissel sal daar 'n mirteboom groei. (Die feit dat die doringbos en die dissel sal verdwyn, dui op die opheffing van die vloek oor die skepping in Gen. 3:18 deur God uitgespreek.) God sal die eer ontvang en die mense vrede ervaar.

Jesaja 65:17-25 begin met die aankondiging dat die Here 'n nuwe hemel en 'n nuwe aarde gaan skep, waar die ganse skepping van blydskap sal juig en jubel. Onder die diere self sal daar vrede wees: die wolf en die lam sal saam wei en die leeu sal strooi vreet soos 'n bees (v. 25). Tussen mens en dier sal daar vrede heers: die slang sal stof eet en 'n klein kindjie sal met ' $n$ adder speel. Ook tussen die mense self sal daar vrede wees. Ontydige dood sal ook nie meer die mense se vreugde vernietig nie (v. 20)

Hierdie profesieë is soos verskillende bergreekse wat agter mekaar lê. Sodra ons die een bereik het, sien ons dat daaragter 'n volgende lê! Die profesieë het verskillende horisonne van vervulling. Dit dui nie net op die herstel van die volk Israel en hulle stad, en nog later, op die koms van Christus nie, maar ook op die nuwe aarde by die voleinding van die wêreldgeskiedenis. Dit is byvoorbeeld interessant om te sien in hoeveel opsigte dit wat Jesaja van die nuwe aarde sê, ooreenkom met wat Openbaring 21 en 22 later daaroor profeteer. (Vgl. byvoorbeeld Jes. $54: 11,12$ en $60: 11,19,20$.) Openbaring gryp egter nog verder terug na Genesis 1 en 2, want ons hoor weer van die rivier met die water van die lewe, die boom van die lewe en nog meer.

Die hoofsaak wat ek wil beklemtoon, is dat die Bybelse toekomsperspektief - anders as wat baie Christene glo en totaal anders as byvoorbeeld die Oosterse religieë - baie konkreet en aards is. Ons is vir hierdie aarde geskep en sal vir dieselfde aarde herskep word, 'n aarde 
wat self ook vernuwe, herskep sal word. Ons bestemming is nie ' $n$ skaduagtige of engelagtige bestaan in die hemel nie.

Dit alles bevestig weer eens hoe belangrik God se skepping hier en nou is!

Ons eerste hoofpunt was God se verhouding tot sy skepping. Die tweede was die skepping se verhouding tot God. Ons gaan nou oor na die derde hoofpunt:

\subsection{Die plek van die mens in hierdie verhouding}

By die aanskoue van die ontsaglike hemelruim besef die mens - dikwels so belangrik in sy eie oë - hoe ' $n$ nietige skepsel, 'n onbeduidende stoffie in ruimte en tyd hy werklik is. Die digter van Psalm 8 (v. 4-5) moes al, toe hy na die nagtelike hemel opgekyk het, vra "Wat is die mens?"; wat is die sin van sy bestaan? Met al die kennis wat ons vandag van die heelal het, word dit 'n nog dringender vraag. Gideon Joubert maak met sy Die groot gedagte (1997:302) ons opnuut daarvan bewus hoe nietig ons werklik is: "Ons, note in die groot lied van die skepping, is vir 'n stonde deel van die Magnificat, dan is ons ook verby. Die orreltone eggo weg in die oneindige".

In sy antwoord op die vraag. "Wat is die mens?" gryp die digter van Psalm 8 (v. 6-9) terug na die Genesisverhaal waar daar staan dat die mens na die beeld van God geskep is, dat die hele res van die skepping aan hom/haar onderworpe is, dat hy/sy daaroor heers

Die feit dat God se opdrag aan die mens (in Gen. 1:26) om oor die skepping te heers, voorafgegaan word deur die openbaring dat God die mens (man en vrou) na sy beeld geskape het, is baie belangrik. Daar word nie gesê wat dit presies beteken nie en dit word ook net op 'n paar plekke in die Skrif herhaal dat die mens die beeld of gelykenis (die twee woorde beteken ongeveer dieselfde) van God is.

\section{God se beeld beteken om sy verteenwoordiger te wees}

Beeld van God kan nie beteken dat die mens letterlik soos God lyk of selfs net gedeeltelik soos Hy lyk nie. (Vgl. wat vroeër reeds oor die radikale verskil tussen God en sy skepping gesê is.) Die Nuwe Vertaling vertaal dan ook "beeld en gelykenis" met "verteenwoordiger en beeld"'. Die woord "verteenwoordiger" mag nie verkeerd verstaan word nie. Die mens is nie meester van die skepping nie, slegs rentmeester, nie maghebber nie, slegs gemagtigde, nie plaasvervanger van God nie, maar alleen sy verteenwoordiger of bestuurder. 
' $n$ Rentmeester moet dit waaroor hy as trustee aangestel is, ken om dit goed te kan bestuur. Die mens is die enigste skepsel wat dié kennis in woorde of taal kan uitdruk. Dit blyk reeds duidelik daaruit as in Genesis (2:19) vertel word dat God al die lewende wesens na die mens gebring het sodat hy hulle kon benoem

Om die beeld van God te wees, beteken dus nie om soos God (Goddelik) te wees nie, maar om soos God te heers of regeer oor die skepping. God doen dit nie op 'n despotiese wyse nie, maar op ' $n$ vaderlike manier, met 'n sagte hand.

\section{Christus as ons voorbeeld}

Uit die lewe van Christus, dié beeld van God (2 Kor. 4:4; Kol. 1:15 en Heb. 1:3) - na wie se beeld ons ook vernuwe moet word - kan ons aflei wat hierdie gesag en mag oor die skepping werklik inhou. Vroeër ( $\mathrm{vgl}$. 2.3 hierbo) is reeds verwys na Filippense 2:5-8 waar gesê word dat Christus die gestalte van 'n dienskneg, 'n slaaf aangeneem het. Om waarlik te heers, beteken om te dien!

Soos reeds gesê, het Christus tydens sy omwandeling op aarde ook sy dissipels daaraan herinner: Hy het nie gekom om gedien te word nie, maar om te dien. Dieselfde moet ook vir hulle geld: "Elkeen wat in julle kring groot wil wees, moet julle dienaar wees; en elkeen wat onder julle eerste wil wees, moet 'n slaaf wees" (vgl. Matt. 20:25-28).

Christus leer dit nie net nie, maar doen dit ook. Volgens Johannes 13 het Hy Homself verneder deur die veragtelike werk van 'n slaaf te verrig en al sy dissipels se vuil voete te was. Aan die einde ( $v$. 15) herinner $\mathrm{Hy}$ hulle egter daaraan dat hulle sy voorbeeld moet navolg. Wat Hy ten slotte daarby voeg, is van groot belang vir ons huidige onderwerp: "'n Slaaf is nie belangriker as sy eienaar nie, en ' $n$ gesant is ook nie belangriker as die een wat hom gestuur het nie" (v. 16).

As God in Christus sy skepping dien, behoort ons dit des te meer te doen! Om oor God se skepping te heers, beteken om dit te dien. Dit is presies die omgekeerde as ons antroposentriese instelling waarvolgens die res van die skepping die mens sou moet dien!

\section{Die betekenis van "bewerk" en "bewaak"}

Hierdie feit word bevestig as ons kyk na God se opdrag aan die mens in Genesis 2:15, naamlik om die skepping te bewerk en te bewaak (of op te pas in die NV). Bewerk is 'n vertaling van dieselfde Hebreeuse woord wat elders in die Ou Testament vertaal word met dien! Bewaak of oppas is weer die vertaling van 'n Hebreeuse woord wat elders in die Ou 
Testament met beskerm (behoed of bewaar in die OV) vertaal word, byvoorbeeld in die hoëpriesterlike seen (Num. 6:24) en in Psalm 121, waarin dit verskeie kere voorkom.

'n Mens sou dus kon sê dat Genesis 2:15 se "bewerk en bewaak" wat ook as "dien en beskerm" vertaal kan word, die "heers" van Genesis 1:26 kwalifiseer. Dit sê hoe ons oor God se skepping moet heers - soos God self dit wil hê! As God se verteenwoordigers dra ons nie minder verantwoordelikheid (as wanneer ons eienaars van die skepping sou wees) nie, maar juis groter verantwoordelikheid. Ek dink dat ons groot probleem is dat ons nie naastenby besef hoe ' $n$ ontsaglike groot verantwoordelikheid werklik op ons rus nie!

Ek herhaal dat hierdie nie tot 'n bloot "geestelike" of "godsdienstige" verantwoordelikheid vereng mag word nie. God beveel Adam en Eva nie om 'n godsdiensoefening te hou of 'n kerk te bou nie! Hierdie eerste opdrag van God aan die mens word tereg die kultuurmandaat genoem. Dit moet in die omvattende betekenis van kultuur, wat ook die godsdienstige insluit, verstaan word. ' $n$ Mens sou dit ons allesinsluitende religieuse roeping kon noem. Dit is nie iets sekulêrs, teenoor evangelieverkondiging as iets heiligs nie.

' $n$ Belangrike rede vir die weinig belangstelling onder Christene in hulle natuurlike omgewing is dat hulle hierdie omvattende kultuuropdrag nie meer ken nie. Hulle weet alleen van Christus se sendingbevel in Matteus 28:19, 20 en vereng die evangelie daartoe. In werklikheid is die "sendingopdrag" slegs 'n herhaling van die oorspronklike opdrag in Genesis. Dit blyk onder andere duidelik daaruit dat Christus sy dissipels opdrag gee om die nasies te leer om alles te onderhou wat Hy hulle geleer het. Wat Hy hulle geleer het, is wat die Ou Testament vanaf Genesis geleer het!

Onderweg na die volmaakte paradys en 'n nuwe lied deur die ganse skepping

Dit is opmerklik dat die Bybel self nie - soos ons dikwels dink - die tuin van Eden met die woord "paradys" aandui nie. (Die woord word net drie keer in die Bybel gebruik en dui elke keer op toekomstige heerlikheid.) Die rede hiervoor is moontlik die bedreiging deur die bose in die eerste paradys. Die uiteinde was dat Adam en Eva tot sonde verlei is. In plaas daarvan om saam met die skepping 'n loflied tot eer van God te sing, gebruik hulle die bome om vir God weg te kruip, sodat Hy moet vra: "Waar is jy?" (Gen. 3:8,9). Wat het geword van jou roeping, die sin van jou bestaan om My te dien en te loof? Die mens word uit die tuin uitgedryf en engele (gerubs) moet sorg dat God se straf uitgevoer word (Gen. 3:24). 
By die geboorte van Christus hoor ons nie van mense wat sing nie. (Ons lees alleen van Maria se lofsang voor sy geboorte.) 'n Menigte engele sing egter (Luk. 2:13,14), nie in die hemel nie, maar op die aarde. In die eerste plek bring hulle die eer aan God in die hemel, maar hulle verkondig ook vrede op aarde vir die mense in wie God ' $n$ welbehae het.

Wanneer Christus sterf, skeur die voorhangsel voor die allerheiligste met sy geborduurde gerubs van bo na benede middeldeur (Matt. 27:51) - ' $n$ teken dat die geslote paradys deur sy versoeningswerk weer geopen is.

Die ware paradys sal egter eers aanbreek op die nuwe aarde waarvan Openbaring profeteer. Daarom staan die lofprysing daar sentraal. 'n Nuwe lied word gesing, deur 'n volledige koor wat engele, mense, stof, plant en dier insluit. In Openbaring 4:11 lees ons van die vier lewende wesens en die 24 ouderlinge (verteenwoordigers van die mensheid) wat God prys omdat Hy die Skepper van alles is. Openbaring 5:9-13 vertel van mense, miljoene der miljoene engele en alles wat in die hemel en op die aarde is wat 'n nuwe lied tot eer van God sing. Net so praat Openbaring 7:9-12 van 'n groot menigte engele om God se troon en Openbaring 14:3 van 'n menseskare van 144000 (die getal van volheid) wat 'n nuwe lied sing.

Dit is duidelik dat die skeppingslied tot eer van die Skepper hier sy hoogtepunt, sy klimaks bereik. Dit is nie meer die gedempte lied, dikwels onderbroke en vermengd met sugte, wat ons tans ken nie.

Om al hierdie pragtige prinsipiële riglyne nie in die lug te laat bly hang nie, volg hier nou 'n paar konkrete riglyne.

\section{Enkele praktiese wenke om mee te begin}

Die volgende is slegs enkele voorbeelde om $u$ te stimuleer om self meer en nog oorspronkliker dinge te bedink.

- Ons moet meer weet van al die wondere van God se skepping. Klein kindertjies kan nog grootoog van verbasing en verwondering die kleinste insek dophou. Volwassenes verloor hierdie gawe as hulle dit nie doelbewus stimuleer nie. Ons kan nie sonder kennis van die natuur God se skepping geniet en waardeer nie. Hoe kan ons as "dirigente" van die skeppingskoor optree en die woordlose lied in woorde vertaal as ons nie die individuele lede van die kosmiese koor ken nie?

- Ons moet weer geleenthede skep om - met ons gesinne en families werklike natuurvakansies te hou, so na as moontlik aan die natuur, met die mins moontlike bykomstighede om ons aandag van God se 
Geleentheidsrede: Die sinvraag

skepping af te trek. Die doel moet wees om van die natuur te leer, dit te waardeer, te geniet en God daarvoor te prys.

- Kerkgroepe kan 'n belangrike bydrae lewer deur doelbewus sterker op die fisies-biologiese kant van die skepping te konsentreer.

- In die eerste plek vergader ons in kerkgeboue, agter dik mure en gekleurde, selfs gebrandskilderde glas, wat ons van die natuur afsonder. Wat van deursigtige vensters wat God se sonlig kan inlaat en ons toelaat om die skepping daar buite te sien? Wat van 'n erediens vroeg Sondagoggend met sonsopkoms? As 'n mens na die tabernakel van Israel kyk (vgl. Eks. 26) en ook die latere tempel van Salomo (1 Kon. 6:27-35), dan sien ons dat die "kerkgeboue" bedoel was om die volk aan die tuin van Eden te herinner: dit was versier met geborduurde gerubs, blomknoppe en palmtakke!

- In die tweede plek is Sondag nie net 'n dag om die verlossing deur Christus (sy opstanding uit die dood) te herdenk nie. Soos ons reeds gesien het, is dit ook ingestel omdat God op dié dag van sy skepping geniet het, daar vreugde in gehad het. Vier ons ook met vreugde op dié dag God se skeppings- en herskeppingswerk?

- In die derde plek behoort skepping en herskepping ook sterker in ons kerklike liturgieë te figureer. Gewoonlik word net hoofmomente uit die lewe van Christus (bv. sy geboorte, dood, opstanding, hemelvaart) herdenk. Dit was nie so in die Ou-Testamentiese kerk nie - verskeie feeste (bv. die loofhuttefees) was aan jaargetye verbind. Ook die vroeë Christelike kerk het 'n ryker liturgie gehad. Waarom kan ons eie liturgie nie ook die viering van die seisoene, soos lente en herfs, insluit nie?

- 'n Laaste, maar baie belangrike wenk, is dat in die prediking meer aandag gegee moet word aan ons verantwoordelikheid, nie net om God se skepping te geniet nie, maar om dit ook te dien. Ons kerkgemeenskappe kan baie meer skeppingsvriendelik, of "groener" word!

- 'n Hele rits ander algemeen bekende moontlikhede sou hierby gevoeg kon word, soos byvoorbeeld die vermyding van onnodige plastiekverpakking, die herwinning ("recycling") van papier (om bome te beskerm), die spaarsame gebruik van grondstowwe en energie, die beskerming van bedreigde plant- en dierespesies en die natuur self, die steun aan natuurlewe-organisasies en ekologiese bewegings en nog baie meer. 
- Kom ek pas dit ook toe op ons Universiteit. Christelike wetenskap gaan in essensie daarom dat mense gehelp word om God se skepping beter te leer ken, verstaan om dit reg te kan bewerk, beskerm en - vergeet nie - te geniet. Dit is die plek waar verwondering oor die oneindige rykdom van God se skepping moet bloei, want ' $n$ universiteit het te make met feitlik elke aspek van God se handewerk. 'n Christelike universiteit moet dus die voorsinger in die kosmiese koor soli Deo gloria! wees. Op die wyse antwoord ons op intellektuele wyse die tergende sinvraag en word ons akademiese taak 'n Goddelike roeping wat oorloop van sinvolheid.

My vrees is egter dat ten minste die volgende ses misleidende ideologieë tans meeding om die sinvraag vir die PUK te beantwoord. In die beperkte tyd kan ek hulle net noem sonder om hulle eienskappe en gevolge te beskrywe: die neo-positivisme, neo-pragmatisme, neo-kapitalisme, neoskolastiek, neo-modernisme (alias postmodernisme) en neo-apartheid

Wanneer ek in die slotgedeelte van dié betoog enkele fragmente van my lewensverhaal met $u$ deel ter toeligting van die taak wat aan my opgedra was, sal u ná die voorafgaande weet wat een van my geheime van oorlewing was. Dit was dat my veeleisende taak uitgevoer kon word deurdat ek en my gesin gereeld na die Drakensberge kon "wegvlug". Dáár, in 'n ongerepte bergwêreld, het God weer vrede, rus en genesing geskenk vir 'n moeë, soekende, stormagtige en dikwels gebroke gees. Dáár, was dit moontlik om opnuut te droom. Dáár het telkens wyer horisonne oopgegaan.

\section{Die sinvraag in my taak aan die PUK}

Dit het tradisie geword dat personeel wat by Filosofie emeriteer in ' $n$ geleentheidsrede op hulle werk in die Departement terugkyk. Hierdie terugskouing - ook op my IRS-werk - is vir my om die volgende redes die moeilikste deel van hierdie praatjie: (1) Omdat ' $n$ mens so nou daarby betrokke was, ontbreek die nodige afstand om jou eie werk te kan evalueer. (2) Veral wanneer ' $n$ mens met hart en siel by 'n saak betrokke was, is dit verder moeilik om die persoonlike en die saaklike van mekaar te skei. (3) 'n Mens kan baie maklik voor die versoeking val om jou eie taak te oorskat en selfs te romantiseer. (4) 'n Mens kan baie maklik die groter wysheid, waaroor jy vandag beskik as jy terugkyk, in die situasie van destyds inlees en maak asof jy toe oor onfeilbare insig beskik het!

Ek probeer na die beste van my vermoë hierdie probleme oorbrug deur my terugblik te doen na aanleiding van die vraag hoe die antwoord op die sinvraag die afgelope kwarteeu in my werk aan die PUK ontplooi het. Soos die wit lig van die son deur ' $n$ prisma in al die kleure van die 
reënboog oopgaan, so is die sinvraag ook veelkleurig, dit het in verskillende aspekte van my werk na vore gekom.

\subsection{Voorbereidende jare}

Soos baie van my studente vandag nog glo, het ek ook gedink dat ' $n$ mens alleen 'n sinvolle lewe kan hê as mens die Here voluit in die kerk kan dien en die evangelie uitdra. Daarom wou ek vir sendeling studeer. Toe maak ek op die PUK kennis met die Reformatoriese lewensvisie met 'n veel breër perspektief op die sin van die lewe: oral, altyd, op elke terrein en in elke beroep - hoe beskeie ook al - kan ons in diens van God se allesomvattende koninkryk staan. Ek is geboei deur die Reformatoriese filosofie wat hierdie bevrydende lewensbeskoulike perspektiewe op wetenskaplike wyse verwoord. Ek het byna 'n "beroepstudent" geword, want na my teologiese studie sit ek my filosofiese studies aan die PUK en die Vrije Universiteit in Nederland voort

So berei die Here elkeen van ons voor vir ons lewenstaak - dikwels sonder dat ons dit besef. Eers later sou blyk hoe noodsaaklik my lewensbeskoulike belangstelling en filosofiese en teologiese skoling vir my werk was. Die Christelik-lewensbeskoulike en wysgerige sou later die twee fokuspunte van my lewenstaak word by respektiewelik die IRS en in die Departement Filosofie.

Ook dit wat eers na 'n "intermezzo"' in my lewe gelyk het, naamlik my vierjarige dosentskap aan die Universiteit van Fort Hare (1970-1974), het later geblyk noodsaaklike voorbereiding te wees vir my eintlike roeping. Dáár kon ek eerstehands kennis maak met 'n vir my toe nog grootliks onbekende kant van die Suid-Afrikaanse samelewing, ons swart mense. Ek leer die Xhosakultuur van naby ken. Ek begin my verdiep in Afrikafilosofie. As redakteur van die nuwe Christelike tydskrif, Umtombo

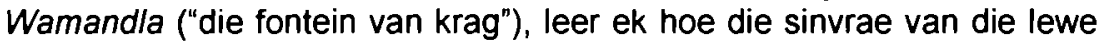
vir 'n Christen in 'n Afrikakonteks beantwoord word. Aan hierdie inrigting, waar vroeër reeds soveel leiers uit verskillende Afrikalande opgelei is, word ek destyds verplig om myself af te vra wat die waarde van ' $n$ Reformatoriese lewensvisie en filosofie is vir die opleiding van die intellektuele swart leiers van die toekoms. (Sommige van hulle beklee vandag hoë regeringsposte.) Ek worstel verder met die sinvraag op politiek-sosiale terrein: die ideologie van apartheid kon tog onmoontlik sinvol wees! Dit vernietig eerder alle sin, omdat dit die waarde van die mens en die res van die skepping - wat God self geseën het - ontken. Lewer ander ideologieë 'n beter oplossing? 


\subsection{Meer en wyer vensters gaan oop by die IRS}

Laat my toe om met die beeld van een na die ander venster wat oopgegaan het, net enkele bakens, grepe of belangrike ontwikkelinge in die taak aan my opgedra aan die IRS uit te lig.

\section{- Venster op die Suid-Afrikaanse Calvinisme}

Die Instituut vir die Calvinisme (IBC) is in 1962 deur 'n paar entoesiaste in die lewe geroep met die ideaal dat hierdie lewensvisie teoreties en prakties verder vir Suid-Afrika uitgebou moet word. Ek is in 1974 na die PUK geroep om as 't ware die Calvinisme verder "in te kleur".

Dit gebeur onder andere in verskillende navorsingsprojekte met behulp van die Raad vir Geesteswetenskaplike Navorsing (RGN). Die bedoeling was om sowel die nalatenskap van Calvyn, die geestelike vader van hierdie tradisie, as die Calvinistiese tradisie self, soos dit in Suid-Afrika gestalte gevind het, te ondersoek. Eers word dus 'n omvattende Calviniana-bibliografie opgestel, wat ook deur die bekende uitgewery E.J. Brill in Leiden, Nederland uitgegee word en later jaarliks in Calvin Theological Journal (Grand Rapids, VSA) voortgesit is. Dan volg 'n omvattende, vierdelige bibliografie, Die inslag van die Calvinisme in Suid-Afrika, met tydskrifartikels oor verskillende aspekte van die Suid-Afrikaanse Calvinisme. Dit is vandag nog steeds ' $n$ handige naslaanbron. Hierdie bibliografiese werk het aangetoon dat daar in die loop van die geskiedenis veel meer oor die Calvinistiese lewensvisie en sy implikasies vir verskillende lewensterreine geskryf is as wat baie gedink het.

Op grond daarvan kon inhoudelik verder navorsing gedoen word en is verskeie monografieë gepubliseer, asook die reeks Calvyncauserieë (F4 van die Wetenskaplike Bydraes van die $\mathrm{PU}$ vir $\mathrm{CHO}$.)

Dit alles lei tot ' $n$ nuwe belangstelling in Calvyn en die Calvinisme in Suid-Afrika. Twee voorbeelde daarvan is die Suid-Afrikaanse Calvynnavorsingskongresse, waarvan die IBC verskeie reel, asook hulle referate publiseer. Verder lei dit tot die eerste volledige vertaling en publikasie in Afrikaans van die eerste (1536) en finale (1559) uitgawes van Calvyn se hoofwerk, die Institusie (vertaal deur H.W. Simpson en uitgegee deur die Calvyn-Jubileum Boekefonds).

\section{- Venster op die hele Reformatoriese tradisie}

Dit het geleidelik duidelik geword dat die Reformatoriese tradisie nie beperk kon word tot Calvyn alleen nie. Met erkenning vir sy reuse bydrae, het dit tog ook duidelik geword dat alle antwoorde nie na Calvyn teruggevoer kan word nie. Die sestiende-eeuse Reformasie bevat ook 
ander rykdomme! Verder is dit nie beperk tot die sestiende eeu alleen nie. Sowel daarvoor, in die vroeë Christendom (bv. Augustinus), as daarna (bv. Abraham Kuyper en sy opvolgers), is waardevolle bydraes gelewer.

Die IBC se vensters word dus wyer oopgemaak. Die populêre reeks Reformatoregalery laat vir baie Suid-Afrikaners die boeiende geskiedenis en blywende waarde van vroeëre en ook moderne reformatore herleef! In ooreenstemming hiermee word die naam van die Instituut ook verander van die IBC na die Instituut vir Reformatoriese Studie (IRS).

\section{- Venster op Christelike Hoër Onderwys}

Die IBC help om hierdie venster wyer oop te maak met die aanbieding van die Eerste Internasionale Konferensie van Gereformeerde Instellings vir Christelike Hoër Onderwys (Sept. 1975). Vir die eerste keer word die vraag gestel wat Christelike hoër onderwys in internasionale konteks beteken. Ons pluk vandag nog steeds die vrugte van hierdie mylpaal 25 jaar gelede. Enkele voorbeelde is die volgende: (1) Dit is met verskeie soorgelyke internasionale konferensies in ander wêrelddele (bv. twee keer in die VSA, in Nederland en Zambië), asook talle streekkonferensies opgevolg waarvan ook die lesings gepubliseer is - verskeie deur die IRS. Vandag staan hierdie aksie bekend as die International Association for the Promotion of Christian Higher Education (IAPCHE) met sy hoofkantoor by Dordt College, Sioux Center, VSA. (2) Die IRS behartig vir 'n hele paar jaar 'n Internasionale Klaringshuis vir Christelike hoër onderwys en versprei informasie oor Christelike onderwys wêreldwyd deur middel van 'n tydskrif, genaamd Circular. Dié tydskrif word later Orientation - wat op 'n stadium in nie minder nie as sestig verskillende lande gelees word! (3) As gevolg van internasionale kontak wat tydens die eerste konferensie gelê is, kom 'n stroom studente - veral uit SuidKorea - aan die PUK studeer. (4) 'n Buro vir Buitelandse Betrekkinge kom aan die PUK tot stand. (5) Die IRS begin 'n fonds wat bekend staan as "CHO-Internasionaal".

\section{- Venster op Afrika}

Veral vanaf die begin van die tagtigerjare is begin besef dat die IRS ook in Afrika ' $n$ taak het. Met groot moeite as gevolg van die boikotte teen Suid-Afrika maar ook groot sukses, word brûe gebou na verskillende Afrikalande en met leidende Christelike denkers dwarsoor ons kontinent. Behalwe dat baie van hulle na IRS-konferensies uitgenooi word en aan IRS-publikasies meewerk, onderneem ek self ook studie- en lesingreise na talle Afikalande om die geestesklimaat buite Suid-Afrika te verken. 
Die bevinding was dat, hoewel die Christendom in Afrika vinniger as op enige ander kontinent gegroei het, dit net so vinnig kan agteruitgaan indien dit nie deur 'n stewige Christelike lewensvisie ondersteun word nie. (Hierdie bevinding word later deur ander Christelike Afrikaleiers onderstreep.) Die "ploegwerk" wat sendelinge die afgelope eeu op die kontinent gedoen het - ook dit kon ek bewonder - moet dringend met die wyer en dieper perspektiewe van 'n Reformatoriese lewensvisie ondersteun word. Dit word duidelik hoe ver en wyd die "stem van Potchefstroom" gehoor kón word. Die ekumeniese betekenis van 'n Reformatoriese lewensvisie oor land-, kerk- en tydsgrense kom in visier!

Verskillende Afrikakonferensies word deur die IRS aangebied, sommige in samewerking met internasionale organisasies soos die reeds genoemde IAPCHE en ook International Association for Reformed Faith and Action (IARFA). Met laasgenoemde organisasie se finansiële hulp word byvoorbeeld in 1987 die "Christian Literature Project for Africa" van stapel gestuur. Hierdie projek het gespruit uit die ontsaglike behoefte aan leidinggewende Christelike lektuur wat werklik relevant is vir die Afrikakonteks. Dit moes ook as teenvoeter dien vir die lektuur uit Bybelvreemde lewensbeskoulike hoeke, soos byvoorbeeld die kommunistiese lektuur wat in massas feitlik gratis in talle Afrikalande versprei is.

Die bedoeling daarvan was dus om aan Christene uit Afrika die geleentheid te bied om self vir Afrika vanuit 'n Christelike perspektief oor die brandende vraagstukke van die kontinent te skryf. Verskeie "skryfskrums" in verskillende Afrikalande het daarop gevolg. Die IRS pluk nog steeds die vrugte daarvan, soos blyk uit die jongste publikasie, 'n standaardwerk deur dr. Yusufu Turaki van Nigerië, wat eersdaags by die IRS sal verskyn: "Christianity and African gods; a method in theology".

Hoe graag sou ek vanaand nie liewer net verhale wou vertel nie! Verhale uit Afrika. Tragiese en komiese, menslike en onmenslike, neerdrukkende en verheffende verhale. Verhale van ontmoetings met mense soos Kenneth Kaunda van Zambie, aartsbiskop Livingstone Nkoyooyo van Uganda, dr. Tukunboh Adeyemo van Kenia, dr. Yusufu Turaki van Nigerië, ons eie aartsbiskop Desmond Tutu. Ek besef vandag eers hoe 'n besondere voorreg die Here my gegee het - en hoe dit my taak aan die PUK beinvloed het - om in gesprek met sulke geestelike reuse oor die karakter en sin van die Christendom op ons bloeiende kontitent te kon besin. Soms het ek by die rand van Afrikapessimisme omgedraai, soos die keer toe ek (in April 1994) naelskraap die menseslagting in Ruanda vrygespring het. Maar steeds was dit vir my 'n ontsaglike ryk voorreg en ryk leerskool. Ek sal die PUK altyd daarvoor dankbaar bly, omdat dit destyds min mense beskore was. 
Vandag - al weer byna twintig jaar later! - is ook Suid-Afrika deel van hierdie ontsaglike groot kontinent, deel van die terra incognita wat ek toé ontdek het. Nog steeds verromantiseer ek dit nie, maar ek het hierdie aarde en sy mense lief. Ek sal dit nooit kan verruil vir die koue en saaklike individualisme van baie mense in Europa of in die VSA nie. Ek voel my geborge in die warmte en rykdom van Afrika se klem op die gemeenskap.

\section{- Venster op die wêreld}

Kyk ons vandag na die IRS, dan besef ons dat die Instituut se vensters uiteindelik so wyd oopgemaak is dat dit die aardbol omvat het. Dit het aan die Reformatoriese lewensvisie en wetenskap vlerke gegee, sodat dit die uithoeke van die wêreld kon bereik. Vir Christene in afgeleë plekke het dit 'n wyer lewensperspektief gegee en hulle met nuwe lewensin vervul.

Maar dit was nie net 'n eenrigtingverkeer vanaf die IRS na buite nie. Die omgekeerde het ook gebeur. Talle buitelanders het nie net die PUK deur die werk van die IRS leer ken nie. Ons is ook deur hulle tydens besoeke, bywoning van talle konferensies en bydraes tot ons verskillende publikasiereekse verryk.

Sonder hierdie wêreldwye netwerk sou die IRS nooit kon wees wat hy geword het nie. Terwyl die IRS tot 'n ekumeniese sentrum van internasionale belang uitgegroei het, is dit jammer - tragies - dat dit vanaf 1990 gerasionaliseer is en op 31 Desember 1999 gesluit gaan word.

\section{- Venster op Suid-Afrika en die PUK self}

Die wêreldwye konteks waarbinne die IRS uiteindelik gewerk het, het nie beteken dat dit sy eie bodem vergeet het nie. By wat reeds hieroor aan die begin gesê is, kan die volgende bygevoeg word: As Instituut was die IRS uniek in die opsig dat dit lede gehad het (wat tussen 900 en 1200 gewissel het) waarvan die grootste aantal binne Suid-Afrika was. Tot 1990 kon hulle deur middel van 'n jaarlikse Algemene Ledevergadering ook die rigting van die IRS help bepaal - hulle bydrae was nie beperk tot die betaal van ledegelde en die aankoop van IRS-publikasies nie.

Omdat hierdie lede uit alle lae van die bevolking en verskillende beroepe gekom het, moes die IRS, behalwe stewige wetenskaplike werke, ook op meer populêre wyse die betekenis van 'n lewe coram Deo, voor die aangesig van God, vir hulle verduidelik. Dit is veral gedoen deur middel van die besonder populêre Reeks F1: IRS-Studiestukke, wat maandeliks verskyn het en waarvan tot op datum 384 nommers die lig gesien het. 'n 
Ander voorbeeld is die gewilde "Venster-reeks" (Venster op die kerk, huwelik, gesin, ideologie, kuns, sake-etiek ens ).

Behalwe die byna 400 studiestukke het die IRS die afgelope 37 jaar van sy bestaan ook 75 brosjures (werke van groter omvang as die studiestukke) en 51 versamelwerke (van nog groter omvang) voorberei en self gepubliseer. Dit nog afgesien van 'n aantal Calvyncauserieë. Bo en behalwe hierdie vier reekse $(F 1,2,3$ en 4$)$ in die PUK se reeks Wetenskaplike Bydraes, ook nog die Circular, later Orientation en nog later Woord en Daad.

Soos wat die IRS groter belangstelling in die res van Afrika ervaar het, meer buitelandse lede ook elders in die wêreld bygekry het en Engels in Suid-Afrika self belangriker geword het, moes ook meer in dié moderne lingua franca gepubliseer word. Tans word die twaalf studiestukke per jaar byvoorbeeld afwisselend in Afrikaans en Engels uitgegee.

Alles wat die IRS gedoen en gepubliseer het, is nie altyd met entoesiasme verwelkom nie. Ons het lede verloor maar ook nuwes bygekry, omdat hulle gevoel het sekere dinge behoort hard en duidelik in die openbaar gesê te word. Selfs bloot my persoonlike deelname aan die Koinoniaverklaring (1977), The South African Christian Leadership Assembly (SACLA) van 1979 en die latere Nasionale (Christelike) Inisiatief vir Versoening, het weerstand uitgelok.

Hierby moet gevoeg word dat die IRS ook nooit sy "moeder", die PUK self uit die visier verloor het nie. Behalwe vir IRS-lede onder PUKpersoneel, het baie dosente IRS-publikasies in hulle klasse (bv. Wetenskapsleer en Filosofie) gebruik. Tans word 'n stuk of vyf groter IRSpublikasies as handboeke voorgeskryf. Omgekeerd het PUK-personeel waardevolle bydraes tot die werk van die IRS gemaak.

Soms moes die IRS ook sy "moeder" ernstig vermaan. Dit het veral tydens die hoogtepunt van die apartheidsera, gedurende die tagtiger- en begin negentigerjare, gebeur toe die IRS in "lojale verset"" deur middel van verskeie konferensies en publikasies moes duidelik maak dat die PUK ' $n$ ander koers moes vaar om sy Christelike roeping nasionaal en internasionaal te kon nakom. Reeds in 1976 het ekself en ook andere tot die oortuiging gekom (en dit op skrif gestel) dat die Christelik-nasionale lewensvisie van die Suid-Afrikaanse Calvinisme vergiftig en lamgelê is deur 'n uiters gevaarlike dualisme, sodat die singewing wat die Skrif aan ons lewe wil gee, nie uitgeleef kon word nie. Teenoor 'n nasionalistiese inkleur van Christelik-nasionale onderuys, moes die Bybelse singewing beklemtoon word: "Beywer julle allereers vir die koninkryk van God en die wil van God ..." (Matt. 6:33). As ons dit doen, sal ons al die ander 
dinge waaraan ons so naarstiglik vasklou, as geskenk van God ontvang Doen ons dit nie, verloor ons op die ou einde sowel die Christelike as die nasionale!

Dit is te verstane dat die "stoel" wat ek beklee het om my taak uit te voer, soms ' $n$ warm plek geword het. Ook die dilemma om na regs of na links te kies, was soms groot: aan die een kant sleepvoetige, evolusionêre verandering as "oplossing" en aan die ander kant uiterste gewelddadige revolusionêre verandering. Vir myself was die enigste weg die "derde weg" van reformasie. Dit het nie 'n kompromie beteken nie. En dit was ook 'n veel moeiliker pad as die twee ander paaie, maar - en dit glo ek nog steeds - die enigste regte weg.

Die woord "reformasie" was egter vir geeneen van hierdie kampe ("regs" of "links") aanvaarbaar nie. Ten spyte van 'n Reformatoriese verlede, wou die een dit nie doen nie en vir die ander groep was die begrip nie radikaal genoeg nie, dit het vir hulle slegs na oppervlakkige vertoon gelyk het. Om geloofwaardig te kon wees, moes die IRS dus bereid wees om sy Reformatoriese gedagtes onbevrees en konkreet op die SuidAfrikaanse samelewing toe te pas, sonder om doekies om te draai. ' $n$ Baie effektiewe middel in hierdie verband was die talle IRS-konferensies gedurende die dekade van ongeveer 1983 tot 1996, waar Christene in 'n gepolariseerde samelewing oor kerk-, kleur- en politieke grense heen mekaar van aangesig tot aangesig kon ontmoet, van nader kon leer ken en praat oor sáám bestaan in plaas van sáám ondergaan.

\subsection{Die sentrale fokus: Voortdurende reformasie op alle terreine}

Ons antwoord op die eerste sinvraag hierbo was: God het formeer, alles baie goed gemaak. Die antwoord op die tweede sinvraag was: Ook al laat God die eindbestemming van sy skepping nie los nie, is deformasie 'n wesenlike gevaar. Die antwoord op die derde sinvraag was: Ons taak is om in ooreenstemming met God se liefdesgebod en in die krag van sy gees, biddend te reformeer.

Met 'n steeds wyer uitdyende skopus het die IRS vensters oopgemaak op Suid-Afrika, Afrika en die wêreld. Maar die fokus was, in ooreenstemming met sy naam, steeds dieselfde: reformasie. Wat beteken dit in beginsel? Wat beteken dit in praktyk? Hoe moet die ideaal in verskillende kontekste en op verskillende terreine van die lewe bereik word? Op sulke vrae wou die IRS antwoorde bied.

Calvyn het dit al raakgesien - en sy gevleuelde woorde, semper reformanda, geld vandag nog - dat reformasie altyd nodig is. Reformeer ons nie voortdurend nie, dan tree deformasie onherroeplik in! Dit beteken 
B.J. van der Watt

egter nie dat mense en instellings wat reformasie bepleit populer is nie, want hulle stel lastige vrae, spreek mense se gewetens aan.

\subsection{Dit kulmineer in reformasie van die hart}

Ek noem ter afsluiting slegs enkele sulke moeilike probleme wat die IRS die afgelope ongeveer vyf jaar deur middel van sy publikasies aan die orde gestel het. Ons sou hierdie tyd (ongeveer 1994 tot 1999) kon aandui as ' $n$ tyd waarin vele onsin van die verlede ontbloot en verwerk moes word en nuwe sin vir die hede ontdek moes word, sodat daar hoop vir die toekoms kon wees. Die temas was:

- Moet ons die skepping net lees in die lig van die Skrif of tegelykertyd ook die omgekeerde doen: ons feilbare Skrifinterpretasies laat toets deur die roepstemme van pyn en lyding vanuit God se skepping? Verwaarloos ons nie skromelik God se skeppingsopenbaring nie?

- Wat maak ' $n$ mens met skuld teenoor God en jou medemens, soos byvoorbeeld in die geval van apartheid?

- Hoe moet kultuurverskeidenheid in die lig van die Skrif geëvalueer word: as ' $n$ bedreiging of as verryking?

- Wat moet die verhouding tussen die Christendom en 'n toenemende sekulêre samelewing wees?

- Presies hoe moet die Christendom binne die Afrikakonteks gestalte kry, sodat dit relevant is, maar terselfdertyd die eie tradisionele kultuur sal reformeer?

- Wat is die sin en onsin van die Westerse ontwikkelingsideale vir ons land en kontinent?

- Wat is - hier en nou - die diepste sin van ons Christenwees en kerklidmaatskap?

Met hierdie laaste gewetensvraag aan myself en ander sluit ek my loopbaan aan die IRS af. Die antwoord daarop staan in my tweede boek wat vanaand tydens hierdie plegtigheid oorhandig is: Naby God.

Dit wil eerstens vir ons sê dat die hart van reformasie die reformasie van die hart is. Hartgrondige bekering geld nie net mense nie, maar ook instellings en dus ook universiteite soos die PUK wat intellektuele en geestelike leiding behoort te gee.

Dit wil ons tweedens daaraan herinner dat niks of niemand - selfs nie die kerk nie - tussen ons en God mag staan nie. Die kerk moet ons immers juis nader aan God bring. 
Dit wil ons derdens waarsku dat, ook al het ons hoeveel vermag in die koninkryk van God, alles wat ons bereik het - ons hele lewenstaak sinloos is as dit nie deur liefde tot God en ons naaste geïnspireer is nie. Omgekeerd leer die Bybel egter ook dat dit wat deur ware liefde geinspireer en gedoen is - hoe klein ook al - nooit sinloos is nie.

\subsection{Die belangrikste bakens in Filosofie}

Hoewel ek reeds voor 1980 af en toe by Filosofie gehelp het, is ek eers vanaf 1980 tot professor met 'n beperkte leeropdrag in die Departement bevorder en vanaf 1990 moes ek 'n volledige leeropdrag behartig. Ek het my werk by die IRS en in die Departement Filosofie nooit as twee totaal afsonderlike werkterreine beskou nie. Tussen die twee was daar 'n diep simbiose. Die talle aktuele sake waarmee ek op lewensbeskoulike vlak by die IRS gekonfronteer is, het my gedwing om na filosofies-wetenskaplike verdieping te soek. Omgekeerd het my werk in die Reformatoriese filosofie op talle terreine koers en rigting aan my lewensbeskoulike werk by die IRS gegee. Ten spyte van die gevaar dat dit die indruk van 'n blote appendiks mag skep, gee ek ten slotte enkele afsonderlike flitse oor my taak by Filosofie.

Kortliks gestel, was my taak hier om die Reformatoriese filosofie, soos deur my voorgangers en tydgenote aan die PUK, in Nederland en elders in die wêreld te ontwikkel, (1) self beter te leer ken, (2) in my klasse en publikasies so te verwoord dat ander daarin kon deel, dit hulle kon inspireer en (3) waar moontlik nuwe, eie "voetpaadjies" oop te maak, sodat hierdie kosbare tradisie verder kon ontwikkel.

Die breë lyne van my werk in hierdie verband was naastenby die volgende: (1) Aanvanklik het ek sterk belangstelling in die geskiedenis van die filosofie en die wysgerige historiografie gehad. Die fokuspunte hier was die Middeleeue as voorloper en later meer gekonsentreerd die sestiende-eeuse Reformasie. (2) Daarna is groter klem op die sistematiese filosofie gelê met as fokuspunte ' $n$ inleiding in die sistematiese filosofie (as brug tussen lewensvisie en wetenskap), mensbeskouing (antropologie), samelewingsfilosofie, kultuurfilosofie en godsdiensfilosofie.

Wat laasgenoemde betref, moes ek byvoorbeeld antwoorde soek op aktuele vrae in ons nuwe, multireligieuse samelewing, soos die volgende: (1) Hoe vergelyk en evalueer 'n mens die verskillende wyses waarop verskillende godsdienste sin aan die lewe probeer gee? (2) in watter opsig bied die Christendom 'n unieke antwoord op die sentrale sinvraag? (3) Wat is die wesenstrekke van die tradisionele Afrika- 
godsdiens in die vorm van byvoorbeeld ubuntu en die uitdaging van 'n Afrika-renaissance?

\subsection{Oorblywende vrae oor die verlede, hede en toekoms}

Tempus fugit! ' $n$ Mens se lewenstyd vlieg verby. Miskien het ek $u$ te lank na die verlede laat kyk. Om met ' $n$ mens se motor veilig vorentoe te kan $\mathrm{ry}$, is dit egter baie belangrik om gereeld in die truspieël te kyk. Belangrike vrae soos die volgende sal vanaand onbeantwoord moet bly:

- In watter opsigte was my bouwerk aan die IRS en in Filosofie in die verlede onvolledig, skeef, eensydig en selfs kortsigtig?

- Waar staan ons vandag met die IRS en die vak Filosofie?

- Wat is van essensiële belang vir die toekoms op Christeliklewensbeskoulike en filosofiese gebied?

Die vorige oorsig het reeds ' $n$ deur na die beantwoording van die eerste twee vrae oopgemaak. Andere sal dit uiteraard beter, met groter afstand en objektiwiteit, kan beoordeel en evalueer.

Wat die toekoms betref, wil ek ten slotte slegs sê dat die sentrale sinvraag vandag miskien aktueler as ooit tevore is en in die toekoms nog dringender sal word. Ons het in 'n geestelike stroomversnelling beland, 'n totaal nuwe Suid-Afrikaanse en wêreldklimaat. Ou antwoorde pas nie meer nie. Ons het nuwe antwoorde nodig op feitlik elke gebied van die lewe. Daarom is Christelike, lewensbeskoulik-filosofiese leierskap vandag van die allergrootste belang. Myns insiens nog belangriker as toe ek my taak 26 jaar gelede aanvaar het.

\section{Slot: terug na die Prediker}

$\mathrm{Ja}$, hierdie is my slotrede, en tog beskou ek dit nie as die einde nie - 'n geleentheid om te "retire" of af te tree nie - maar as die begin van 'n nuwe tydperk in my lewe - 'n geleentheid om te "refire" of aan te tree! Want die koninkryk van God kan nie met betonheinings afgegrens word tot hierdie klein, plat, vaal, wêreld tussen mielielande en wilgerbome aan die duskant van die Mooirivier nie. Aan die ander kant lê 'n wye, uitgestrekte, honger wêreld wat smag na dit wat hier te dikwels as vanselfsprekend aanvaar word.

Ses-en-twintig jaar gelede het ek met rugsak, stewels en kompas onder aan die voet van 'n berg - my taak aan die PUK - gestaan. Vandag staan ek bo-op die piek. Ek kan nou baie verder sien as 'n kwarteeu gelede. Ek sien die verlede - al die valleie en heuwels ver daaronder - in 
perspektief. Maar vorentoe sien ek ook winkende horisonne, nuwe, onbekende pieke wat roep

Laat my egter afsluit met die slotsom van die diepste filosofiese boek waarmee ek my praatjie begin het. Dit lyk of die eerste gedeelte vir myself geskryf is. Dit lui so: "My seun, wees versigtig! Daar kom nie 'n einde aan die skryf van baie boeke nie, te veel studie ooreis die liggaam" (Pred. 12:12)

Omdat, in ons beginsellose, (neo)pragmatiese tyd met sy soeke na resultate, effektiwiteit en produksie, die woorde van die Prediker vandag selfs nog relevanter is as toe hy hulle neergeskryf het, groet ek die PUK met hierdie woorde:

Moet nooit ophou om na ware wysheid te soek nie en verag nie die filosofiese soeke daarna nie, want: "Die woorde van mense met wysheid is soos prikkels, soos spykers wat diep ingeslaan is. Hulle is deur die enige Herder gegee" (12:11). En vergeet nooit die eenvoudige Bybelse antwoord op die belangrike sinvraag nie: "Die hoofsaak van alles wat jy gehoor het, is dit. Dien God en gehoorsaam sy gebooie. Dit is (al) wat van elke mens - en ook 'n instelling soos die PUK - gevra word" (12:13)

Ons het begin met die woorde van die Prediker (1:2) dat alles tevergeefs is. Ons het gesê die Prediker stel die vraag oor die sin van die lewe, terwyl die res van die Woord van God die antwoord op hierdie belangrike vraag bied. Met hierdie antwoord wil ek graag afsluit. Van die talle moontlikhede uit die Skrif gee ek net twee - een uit die Ou en een uit die Nuwe Testament

Die eerste kom uit 'n pelgrimslied van Salomo, een van die wysste mense wat ooit geleef het:

"Tevergeefs dat julle vroeg opstaan en laat gaan slaap om met moeite 'n bestaan te maak. Vir dié wat Hy liefhet, gee die Here dit in hulle slaap" (Ps. 127:2)

Die tweede is die woorde waarmee Paulus, een van die grootste Christene van alle tye, sy bekende hoofstuk oor die opstanding uit die dood afsluit:

"Daarom my broeders - en ook susters - wees standvastig, onwankelbaar, altyd oorvloedig in die werk van die Here, omdat julle weet dat julle inspanning in diens van die Here nie tevergeefs is nie" (1 Kor. 15:58).

Ek dank u! 


\section{Enkele geraadpleegde bronne}

DE VRIES, J s j Het lied van Gods schepping. Franeker : Wever

DIEMER, J H 1963 Natuur en wonder Amsterdam : Buijten \& Schipperheijn.

HOEZEE, S 1998 Remember creation; God's world of wonder and delight. Grand Rapids, Mıchıgan : Eerdmans

JOUBERT, G. 1997 Die groot gedagte; abstrakte weefsel van die kosmos. Kaapstad : Tafelberg.

KREEFT, P. 1989. Three philosophies of life. San Francisco : Ignatius.

ROSSOUW. HW. 1981. Die sin van die lewe. Kaapstad : Tafelberg.

SIKKEN, W. 1957. Het wonder. Kampen : Kok.

VAN DEN BEUKEL, A. 1992. De dingen hebben hun geheim; gedachten over natuurkunde, mens en God. Baarn : Ten Have. 